\title{
Technical College Students' Perceptions of English for Specific Purposes Vocabulary Learning and Teaching
}

\author{
Lin-Fang $\mathrm{Wu}$ \\ Lecturer, Language Education Center \\ Fooyin University, Taiwan \\ Tel: 886-7-77811151\# 5629 E-mail: en018@fy.edu.tw
}

Received: January 7, 2014 Accepted: January 26, 2014 Published: January 26, 2014

doi:10.5296/ijele.v2i1.4987 URL: http://dx.doi.org/10.5296/ijele.v2i1.4987

\begin{abstract}
The purpose of this study was to investigate the learning difficulties and the preferred teaching method among Taiwanese junior college students while they were taking English for Specific Purpose (ESP) vocabulary courses. Subjects comprised 232 students at the Junior College Division of Fooyin University in southern Taiwan. The ESP vocabulary learning questionnaire designed by the researcher was administered to the selected nursing department students who had enrolled in the medical terminology course as a requirement. In addition, the participants' learning difficulties, learning sources, and attitudes toward ESP vocabulary were under observation for the entire semester. The results of the survey indicated that vocabulary abstractness was the most difficult for most participants, followed by pronunciation, word length, and orthography. Effective ESP vocabulary teaching should be combined with authentic teaching materials to increase learners' learning motivation. The enhancement of pronunciation accuracy for English as a foreign language (EFL)/ESP instructors cannot be ignored. Moreover, word morphology for ESP vocabulary learning should be the priority, particularly for EFL/ESP vocabulary learners.
\end{abstract}

Keywords: English for specific purposes (ESP), vocabulary, collaboration 


\section{Introduciton}

As international communication becomes more accessible and faster, English for specific purposes (ESP) has become an essential branch in English language teaching. Professionals increasingly demand ESP programs to match the development in their own field. A number of ESP programs at technology universities have recently been implemented in Taiwan. Researchers have conducted studies to determine effective teaching approaches and learning strategies for ESP learners. Researchers have indicated that the greatest obstacle for acquiring a second language is limited vocabulary size. ESP vocabulary always presents a major linguistic obstacle to nonnative English-speaking students. Consequently, effective ESP vocabulary teaching plays a crucial role in successfully implementing ESP programs. Nonetheless, ESP vocabulary teaching has been a neglected area in ESP research during previous decades. Researchers and teachers have focused less attention on it than on syntax and phonology. Although ESP vocabulary does not receive as much attention as language specialists suggest, numerous ESP practitioners have advocated the learning of lexical items according to semantic systems (Robinson, 1991). Alber-Dewolf (1984) suggested that a sound knowledge of term-formation processes improves the reading skills required for reading a foreign language for specific purposes. In this study, we investigated effective ESP vocabulary teaching approaches, students' sources of ESP vocabulary acquisition, learning difficulties and learning attitudes. Moreover, effective ESP vocabulary learning strategies, pronunciation accuracy, and team teaching were addressed. The subjects comprised 232 students at Fooyin University. A questionnaire regarding ESP vocabulary learning was distributed to the participating students during classes. Results of the study suggested that ESP vocabulary learning should be prioritized when curriculum specialists are designing ESP instructional materials.

\subsection{Statement of the Problem}

ESP courses are the mainstream of current technical college English courses; however, most technical college students feel frustrated by ESP courses because of a limited vocabulary size. It is a challenge to motivate them to use correct spellings and accurate pronunciation regarding ESP vocabulary. ESP vocabulary learning difficulties include both semantic and phonetic problems. Designing useful and effective ESP courses for technical college students is necessary. Appropriate teaching materials, learning strategies and the interactions between learners and teachers are the essential components to solve learning difficulties. In this study, an investigation of learners' perceptions regarding ESP vocabulary learning was conducted to help language teachers and content teachers understand what learners require.

\subsection{Purpose of the Study}

The purpose of this study was to help language teachers and content teachers understand learners' ESP vocabulary learning difficulties, their preferred teaching methods, and their ESP vocabulary acquisition sources.

\subsection{Research Questions}

1. What are the learning difficulties among technical college students when taking ESP 
vocabulary courses?

2. What is the preferred teaching method among technical college students regarding ESP vocabulary courses?

3. What are the major sources of ESP vocabulary acquisition among technical college students?

\section{Literature Review}

Hutchinson and Waters (1987) indicated that the reasons for the emergence of all ESP programs were the demands of the electronic age, a revolution in linguistics, and the focus on learners. Learner needs for revolutionary linguistics was the main reason for the emergence of ESP programs. The enormous expansion in scientific, technical, and economic activities increased the demand for learning ESP courses. In comparison with the traditional linguists, revolutionary linguists focused on how languages were used in real situations. In their opinions, the English must change when the particular context was given. The effect of ESP development exerted increased pressure on language teaching professions. Ewer (1983) recognized that traditional English teachers were trained in literature and language. They tended to claim English for general purposes as their specialist discipline and displayed a hostile attitude to others, such as English for science and technology, and business and economics. Widdowson (1968) presented two interpretations of learner needs. One was goal-oriented definitions of needs and related to terminal behavior. The other was process-oriented definitions of needs and related to transitional behavior, (i.e., the means of learning). In comparison with traditional linguists, revolutionary linguists have focused on methods in which languages are used in real situations. Swales (1983) indicated that most studies of lexis and ESP were language centered, not pedagogy. Halliday, McIntosh, and Strevens (1964) mentioned that the course design addresses learner needs, such as English for civil servants, for policeman, and for officials of the law. Regardless of learner needs, ESP programs should focus on various learning strategies, schema, motivations, and interests.

ESP materials play an integral role in developing a successful ESP program. Nababan (1993) indicated that specific areas and learner types were the most significant elements for designing ESP teaching programs. ESP teaching materials should be based on a syllabus that covers all of the learner needs in their present studies and future professions. The content can be determined by a need analysis. Several researchers (Halliday, McIntosh, \& Strevens, 1964) have mentioned that designing a course according to the learner requirements regarding the language seemed to be the priority for designing ESP materials. According to the suggestions by Munby (1978) for ESP materials, syllabus specification is directly derivable from prior identification of the communicative requirements of learners. Learner needs should be the first criteria for ESP course design. Once the content has been recorded, analyzed, and organized, teachers will possess efficient learning materials to teach the learners with confidence and certainty.

ESP vocabulary teaching is one of the essential components for educational practitioners to implement successful ESP programs. Vocabulary selection is the most substantial early task 
that serves as the basis for the syllabus structure. The basic procedure for ESP course design is to determine the content of the syllabus regarding linguistic items by reference to primary criteria, such as frequency, range, and coverage (Widdowson, 2000). Wilkins (1976) also indicated that the analysis of the linguistic components of a desired performance and isolating its lexical units are the main principles of vocabulary control. In Wilkins' opinions, the linguistic content is planned according to the semantic demands of the learners. Nababan (1993) mentioned that the vocabulary component is the central core of numerous ESP programs. Vocabulary is the most prominent feature of a register, and words have particular meanings depending on the specific register in which they are used. However, ESP vocabulary always presents a major linguistic obstacle to nonnative English-speaking students. ESP vocabulary learning strategies and storage should be emphasized in ESP classes.

Corpus building is effective for ESP vocabulary learning. ESP vocabulary is the main obstacle when technical college students are taking an ESP class because of limited vocabulary size. Copra instruction can help learners overcome ESP vocabulary learning difficulties. Language teachers have long used lists of essential vocabulary as a guide for course design and materials preparation. Corpora data play a crucial part in developing these word lists (Jones \& Durrant, 2010). Huang (2007) suggested that course design with a textbook-based corpus can promote business students' reading comprehension. Furthermore, corpus data can be used for writing instruction. Flowerdew (2010) indicated that multiple lines of concordance output can reveal grammatical features, collocations, and semantic preferences. Simpson and Mendis (2003) acquired 238 idioms through corpus building. They recommended that corpus-based idioms can raise learners' awareness of speech context. The integration of corpora data with classroom activities should be the focus for ESP and EAP courses.

Vocabulary learning strategies are an effective tactic for ESP vocabulary acquisitions. Establishing a connection between spelling and pronunciation can tremendously enhance ESP vocabulary recognition and reading ability because English is an alphabetic language. Word decoding and recognition ability are vital factors that improve ESP reading comprehension and speed. The knowledge of basic affixes, roots, suffixes, and word formation help learners decode ESP vocabulary. Decomposing an unknown word into its structural components and inferring its meaning from them is called structural analysis. Several researchers (Nation, 1990; Hsueh, 1997) have mentioned that learning a variety affixes can successfully teach students ESP vocabulary structural analysis. By becoming familiar with only a few roots, affixes, and suffixes, students can determine the meaning of many words. In addition, teaching the word formation of ESP vocabulary can help learners memorize and recognize it in an effective manner. Word decoding instruction results in improving learners' ability to infer word meaning.

\section{Research Methodology}

\subsection{Study Subjects}

The subjects in this study were 232 students enrolled in the junior college division of Fooyin 
University (Table1). The respondents consisted primarily of women with an average age of 18-20. They were third-year and fourth-year students in the nursing department. It was stressed that the results would not affect their school grades.

Table 1. Students Sample Distribution

\begin{tabular}{lll}
\hline Subjects & Frequency & Percentage \\
\hline Third-year & 84 & 36.2 \\
Fourth-year & 148 & 63.8 \\
Total & 232 & $100 \%$ \\
\hline
\end{tabular}

Note: Participants were five-year junior college students.

\subsection{Instruments}

\subsubsection{The Questionnaire}

A questionnaire (Appendix) designed by the researcher was used to determine the students' perceptions of ESP vocabulary learning difficulties. The questionnaire is divided into two parts: (a) students' background information, and (b) students' learning difficulties, learning sources, and attitudes toward ESP vocabulary.

\subsection{Data Collection and Analysis}

The ESP vocabulary learning questionnaire was administered to selected nursing department students who had enrolled in the medical terminology course as a requirement. A total of 250 questionnaires were distributed to the participating students. A total of 232 questionnaires were completed, returned, and evaluated. Data were collected by the author, with the assistance of several English teachers at Fooyin University. The author then conducted a series of statistical analyses on the collected data by using Statistical Packages for the Social Science (SPSS). Moreover, results were observed and gathered by the researcher during regular medical terminology classes.

\section{Results and Discussion}

\subsection{ESP Vocabulary Learning Difficulties Among Technical College Students}

English medical terminology is one of the required and more challenging courses during the third year for nursing students at Fooyin University. The results of the survey indicated that vocabulary abstractness was the most difficult for majority of participants, followed by pronunciation, word length, and orthography (Table 2). The volume of unfamiliar vocabulary made learners feel frustrated and anxious, because most medical terminology is multisyllabic words that are longer and more complicated than the commonly used words. In addition, several of the participants expressed that phonetic irregularity was one of the major hindrances for them to achieve effective learning when taking the ESP vocabulary courses. The diverse pronunciation between ESP teachers at schools and clinical instructors in the 
hospital made them feel confused and frustrated. As mentioned in the literature, it is a challenge for low-level students to maintain the motivation to learn correct spelling and accurate pronunciation regarding ESP vocabulary. Kirschner (1992) indicated that an ESP vocabulary course should not be taught before students reach an intermediate level of English language proficiency and an ESP instructor should possess considerable experience as an English as a foreign language or English as a second language instructor before becoming involved in teaching ESP courses. Nonetheless, many participants agreed that medical terminology was beneficial for them during their clinical practicum. In summary, ESP vocabulary teachers should spend additional time teaching accurate pronunciation and vocabulary learning strategies, such as word decoding, suffixes, prefixes, sound-and-spelling consistency, and phonetic irregularity. Learners would thus feel competent and more comfortable when taking ESP courses. Moreover, some of the participants mentioned that 2 hours once a week for a difficult course is not sufficient for ESP vocabulary acquisition. It was suggested that an ESP vocabulary course should be continued for 2 years, and the burden of this course will thereby be reduced.

Table 2. Rank of ESP vocabulary learning difficulties

\begin{tabular}{llll}
\hline Items & Frequency & Percentage & Rank \\
\hline $\begin{array}{l}\text { Vocabulary } \\
\text { abstractness }\end{array}$ & 158 & $68 \%$ & 1 \\
Pronunciation & 146 & $62 \%$ & 2 \\
Word length & 129 & $55 \%$ & 3 \\
Orthography & 108 & $46.6 \%$ & 4 \\
\hline
\end{tabular}

Note: Table 2 is the results of multiple-responses. Each participant can have more than one choice.

\subsection{ESP Vocabulary Teaching Methods}

Lack of qualified ESP teachers has always been the major difficulty in successfully implementing an ESP teaching program. The team teaching approach was considered the optimal approach to deal with the shortage of ESP teachers because few teachers felt competent enough to teach ESP courses. Collaboration is the key element in a team teaching approach to ESP programs. According to the survey (Table 3), collaborative teaching was the preferred teaching method for most of the participants. Nearly $50 \%$ of the participants indicated that subject teachers with proficient English should be qualified and ideal ESP teachers, followed by language teachers, and native speakers. 
Table 3. Rank of Learners' favorite ESP vocabulary teaching methods

\begin{tabular}{llll}
\hline Teaching Methods & Frequency & Percentage & Rank \\
\hline Team teaching & 190 & $82.2 \%$ & 1 \\
Subject teachers & 108 & $46.6 \%$ & 2 \\
Language teachers & 37 & $15.9 \%$ & 3 \\
Native speakers & 10 & $4.3 \%$ & 4 \\
\hline
\end{tabular}

Note: Table 3 is the results of multiple-responses. Each participant can have more than one choice.

\subsection{Sources of ESP Vocabulary Acquisition Among Technical College Students}

Among the participants, $81 \%$ expressed that their major ESP vocabulary learning sources were from general nursing courses, followed by medical terminology classes, and clinical practice (Table 4). More than half of the participants stated that clinical practicum in hospitals was another main ESP vocabulary learning source. Briefly, both subject teachers and ESP instructors were responsible for successful ESP vocabulary learning. Sufficient collaboration between subject teachers and language instructors should be prioritized in ESP team teaching.

Table 4. Rank of ESP Vocabulary Acquisition Sources

\begin{tabular}{llll}
\hline Items & Frequency & Percentage & Rank \\
\hline General nursing courses & 188 & $81 \%$ & 1 \\
ESP courses & 174 & $75 \%$ & 2 \\
Clinical Practice & 131 & $56.5 \%$ & 3 \\
Others & 8 & $3.4 \%$ & 4 \\
\hline
\end{tabular}

Note: Table 4 is the results of multiple-responses. Each participant can have more than one choice.

\section{Conclusion}

According to the results of the survey, vocabulary abstractness was the main difficulty for ESP vocabulary acquisition. The other difficulties the participants mentioned were pronunciation, word length, and orthography. Therefore, spelling-to-sound consistency, accurate pronunciation, word decoding, and morphology should be emphasized when implementing an ESP program. Selected and classified ESP vocabulary based on the teaching materials is unavoidable, particularly for low-level students. ESP vocabulary is more 
complicated than commonly-used words because most of the terminology is multisyllabic. As suggested in the literature (Chen, 1994), ESP vocabulary learning and teaching is the core of an effective ESP learning program. ESP courses should not be taught before students attain an intermediate level of English language proficiency. Brennan and van Naerssen (1989) mentioned that students require an English proficiency level high enough to be sensitive to how language is used in their future profession.

The insufficiency of ESP instructors is another major difficulty in implementing an ESP program. It is a challenge to find qualified ESP instructors because several language teachers feel incompetent regarding ESP vocabulary courses. Ewer and Hughes (1972) mentioned that a language teacher's previous literature-oriented training can cause anti-science bias which is impossible to conceal from students. Team teaching is a method for dealing with the shortage of ESP instructors and it could also help language teachers develop positive attitudes toward diversified disciplines. The results of this survey also indicated that the collaboration of language teachers and subject instructors was the students' preferred teaching method. Another positive aspect of team-teaching is enhancing students' ESP vocabulary learning motivation. Several of the participants indicated that collaborative teaching would be beneficial for them, in particular a Mandarin-speaking nursing teacher and a native English speaker.

The results indicated that team teaching was the preferred teaching approach for nursing students. Subject teachers can teach them knowledge about nursing, whereas language teachers can teach them accurate pronunciation. Although team teaching is a trend for ESP vocabulary courses, there are hindrances to achieve a successful ESP program through a cooperative teaching approach. Robinson (1991) recognized that the impossibility for language and subject teachers to work together in the same classroom because both preferred to retain autonomy in their own teaching. Nonetheless, ESP instructors and language teachers should give up some autonomy which has traditionally been held to be theirs (Robinson, 1991). Dudley-Evans (2001) also recommended that cooperation between language teachers and subject teachers working as equals, and each aware of and respecting the contribution of the other.

Salager (1983) and Coxhead (2000) have mentioned that the size of a corpus that ranging from millions of words of text to one journal article, and selecting appropriate vocabulary from a varied domain should be prioritized to achieve an effective ESP course. Linguists should devote much more time to establishing ESP vocabulary corpora in varied domains. Several researchers $(\mathrm{Su}, \mathrm{Chen}, \& \mathrm{Fahn}, 2007)$ indicated that medical terms and the abbreviations in nurse-and doctor-written notes should be included in medical terminology courses. In addition to the corpora selected by ESP linguists, authentic teaching materials provided by hospitals are an indispensable source for nursing students' acquisition of medical terminology. In summary, collaboration between subject teachers and language teachers, selection of appropriate content, and students' attitudes all exert a substantial effect on the ESP vocabulary teaching programs. 


\section{References}

Alber-Dewolf, R. (1984). Team-formation processes in English, German, French and Russian. Pugh and Ulijn, 25, 166-173.

Brennan, M., \& van Naerseen, M. (1989). Language and content in ESP. ELT Journal, 43(3), 196-205. http://dx.doi.org/10.1093/elt/43.3.196

Chen, H. C. (1994). Team-teaching English for special purposes: a new perspective. Tamkang Journal, 33, 235-252

Coxhead, A. (2000). A new academic wordlist. TESOL Quarterly, 34, 213-238. http://dx.doi.org/10.2307/3587951

Dudley-Evans, T. (2001). English for specific purposes. In R. Carter, \& D. Nunan (Eds.), The Cambridge guide to teaching English to speakers of other languages (pp. 131-136). New York: Cambridge University Press. http://dx.doi.org/10.1017/CBO9780511667206.020

Ewer, J. A. (1983). Teacher training for EST: Problems and method. ESP Journal, 2(1), 9-31.

Ewer, J. E., \& Hughes-Davies, E. (1972). Further notes on developing an English program for students of science and technology. ELT Journal, 26(3), 269-273. http://dx.doi.org/10.1093/elt/XXVI.3.269

Flowerdew, L. (2010). Using corpora for writing instruction. In O'Keeffe, A., \& McCarthy, M. (Eds.), The Routledge handbook of corpus linguistics (pp. 444-457). New York: Routledge.

Halliday, M. A. K., McIntosh, A., \& Strevens, P. (1964). The linguistic sciences and language teaching. London: Longmans.

Hsueh, L. (1997). Teaching English vocabulary and reading in an EFL classroom. Bulletin of National Pingtung Institute of Commerce, 5, 221-240.

Huang, C. C. (2007). Applying a textbook-based corpus to promote business students' reading comprehension. Paper presented at the Proceedings of International Symposium on ESP \& Its Application in Nursing \& Medical English Education, Kaohsiung, Taiwan.

Hutchinson, T., \& Waters, A. (1987). English for Specific Purposes: A learning-centered approach. Cambridge: Cambridge University Press. http://dx.doi.org/10.1017/CBO9780511733031

Jones, M., \& Durrant, P. (2010). What can a corpus tell about vocabulary teaching materials. In O'Keeffe, A., \& McCarthy, M. (Eds.), The Routledge handbook of corpus linguistics (pp. 387-400). New York: Routledge.

Kirschner, M. (1992, October/ November.). ESP A reader responds... TESOL Matters. Munby, J. (1978). Communicative syllabus design. Cambridge: Cambridge University Press. Nababan, P. W. J. (1993). E.S.P. Materials Preparation in a Foreign Languages Situation. 
ERIC Digest. (ED326233).

Nation, I. S. P. (1990). Teaching and learning vocabulary. Boston: MA, Heinle.

Robinson, P. C. (1991). ESP Today: A practitioner's guide. Hempstead: Prentice-Hall.

Salager, F. (1983). The lexis of fundamental medical English: Classificatory framework and rhetorical function. Reading in a Foreign Language, 1(1), 54-64.

Simpson, R., \& Mendis, D. (2003). A corpus-based study of idioms in academic speech. TESOL Quarterly, 37(3), 419-441.

Su, S., Chen, H., \& Fahn, R. (2007). Toward a process-oriented ESP course design for the EFL nursing. Paper presented at the Proceedings of International Symposium on ESP \& Its Application in Nursing \& Medical English Education, Kaohsiung, Taiwan.

Swales, J. M. (1990). Genre analysis: English in academic and research settings. Cambridge, UK: Cambridge University Press.

Widdowson, H. (1968a). Language in Education. Oxford: Oxford University Press.

Widdowson, H. (2000b). On the limitations of linguistics applied, Applied Linguistics, 21, 3-25. http://dx.doi.org/10.1093/applin/21.1.3

Wilkins, D. (1976). National syllabuses. Oxford: Oxford University Press.

\section{Appendix}

Questionnaire on Learning English Medical Terminology

Part I: Personal Information

1. Major:

2. Grade:

Part II: The following are five multiple response questions. You can choose more than one answer.

1. What are the learning resources for your acquisition of English medical terminology?

$\square$ 1. general nursing courses and assignments

$\square$ 2. medical terminology classes

口3. clinical practice

口4. other

2. What is the main purpose for you to learn English medical terminology?

$\square$ 1. preparation for tests 
$\square 2$. continuous study

$\square 3$. job requirement

$\square$ 4. other

3. What are your learning difficulties while learning English medical terminology?

$\square 1$. vocabulary abstractness

$\square 2$ word length

⒊ pronunciation

口4. orthography

口5. other

4. Who would you consider to be the most appropriate teachers for English medical terminology?

$\square$ 1. team teaching (subject teacher \& language teachers)

$\square$ 2. subject teachers

$\square 3$. language teachers

$\square$ 4. native speakers

5. Do you think weekly leaching hours for English medical terminology courses should be increased?

$\square 1$. Yes

$\square$ 2. No

$\square$ 3. other

Part II: Please describe what you have learned and the learning difficulties you have encountered during the English medical terminology classes, and your expectations for the course.

\section{Copyright Disclaimer}

Copyright reserved by the author(s).

This article is an open-access article distributed under the terms and conditions of the Creative Commons Attribution license (http://creativecommons.org/licenses/by/3.0/). 